\title{
Assimilação Ressignificada: Novas Interpretações de um Velho Conceito*
}

\author{
Oswaldo Truzzi
}

Professor associado da Universidade Federal de São Carlos (UFSCar), onde atua nos Programas de Pós-Graduação em Sociologia e Engenharia de Produção, além de dirigir a editora universitária. E-mail: truzzi@ufscar.br.

\begin{abstract}
s discussões sobre modos de incorporação de imigrantes às socieA dades receptoras tornaram-se mais acaloradas na última década. Reflexo de uma nova era de migrações internacionais e da magnitude dos fluxos recebidos no passado, tanto a sociologia histórica americana quanto a argentina procederam a uma revisão do tema. No caso brasileiro e, sobretudo paulista (dado o maior peso dos fluxos a este estado no contexto nacional), estes novos desenvolvimentos teóricos exigem novas interpretações de nossa experiência de recepção de imigrantes estrangeiros.
\end{abstract}

Até os anos sessenta do século passado, o paradigma da assimilação reinava praticamente absoluto, influenciado pelos expoentes mais conhecidos da Escola de Chicago, desde Robert Ezra Park (1921) até Milton Gordon (1964). Esquematicamente, estes argumentaram - geralmente apoiados sobre estudos da chamada "segunda leva" de imigrantes (provenientes da Europa Oriental e Meridional) aos Estados Unidos - que os imigrantes gradualmente haviam perdido (diga-se de passagem, felizmente, para seu próprio bem e da sociedade mais am-

\footnotetext{
* Este artigo foi parcialmente desenvolvido no projeto Observatório das Migrações em São Paulo: Fases e Faces do Fenômeno Migratório no Estado de São Paulo, coordenado por Rosana Baeninger e apoiado pela Fundação de Amparo à Pesquisa do Estado de São Paulo (Fapesp). Agradeço pelos comentários recebidos tanto por ocasião da reunião do GT Migrações Internacionais da Associação Nacional de Pós-Graduação e Pesquisa em Ciências Sociais (Anpocs) em 2011, quanto dos pareceristas da Dados que o avaliaram.
}

DADOS - Revista de Ciências Sociais, Rio de Janeiro, vol. 55, nํ2, 2012, pp. 517 a 553. 
pla, segundo tais autores) sua "identidade étnica", para se integrarem ao mainstream americano.

A partir dos anos setenta, o modelo de assimilação foi contestado e criticado na literatura americana - desde Glazer e Moynihan (1963) até Conzen et alii (1992), entre muitos outros - pelos pluralistas, que o julgaram como irrealista na prática e, ademais, politicamente incorreto, devido a seu pressuposto etnocêntrico e "anglo-conformista" de definir (ou subentender) o que seria o mainstream americano (Persons, 1987; Kazal, 1995). Objeto de intensa polêmica, alguns chegaram a declarar como "morto" o próprio conceito de assimilação (Glazer, 1993). De modo simplificado, desde então, as posições se cristalizaram segundo a dicotomia "assimilacionistas" versus "pluralistas".

O objetivo deste artigo é propor uma interpretação sobre como o termo assimilação foi utilizado no Brasil em três períodos distintos e apresentar uma reconceituação do mesmo baseada na obra Remaking the American Mainstream - Assimilation and Contemporary Immigration, de Richard Alba e Victor Nee, publicada originalmente em 2003. Argumenta-se que a nova formulação proposta por esses autores pode contribuir para uma compreensão mais precisa das diferentes trajetórias de incorporação de grupos de imigrantes estrangeiros à sociedade brasileira, no passado e no presente.

Logo após o seu surgimento e popularização acadêmica nos Estados Unidos a partir dos anos vinte, o termo "assimilação" passou a ser utilizado no Brasil. De lá para cá, podem-se distinguir pelo menos três fases nas quais o conceito foi empregue de formas distintas: em primeiro lugar, o uso que dele fizeram intelectuais preocupados em discutir, promover e alguns deles em preservar ${ }^{1}$ a formação nacional do povo brasileiro, que acabaram por influenciar tanto os rumos da política migratória praticada durante a Primeira República, quanto a política de nacionalização forçada empreendida durante o Estado Novo, conhecida como campanha de nacionalização. Em segundo lugar, o uso propriamente acadêmico e estritamente associado a uma interpretação cultural do termo a partir dos anos quarenta, inaugurado provavelmente com a obra de Emilio Willems, e que se prolongou até pelo menos os anos setenta. Por fim, o período no qual a utilização do termo assimilação caiu em descrédito nos meios acadêmicos, concomitantemente à valorização das identidades étnicas de diferentes grupos de 
imigrantes, do passado e do presente, período este influenciado pela emergência de uma perspectiva multiculturalista.

\section{ASSIMILAÇÃO E A FORMAÇÃO NACIONAL}

Um dos primeiros intelectuais a utilizar o termo no Brasil foi Alfredo Ellis Jr. em seu livro Populações Paulistas, escrito ao final dos anos vinte, mas publicado somente em 1934. Interessado em valorizar a influência das famílias paulistas - que produziram o bandeirismo e, segundo o autor, a formação da lavoura de café - na prática caracterizando-as como o mainstream paulista, o autor distingue entre dois processos de assimilação: o cruzamento e a educação ou adaptação. Trabalha, pois, com uma concepção de assimilação calcada em aspectos de natureza racial e cultural, cujo desfecho se traduz pela aniquilação das culturas alienígenas em favor de uma suposta primazia paulista, considerada uma raça de gigantes:

a assimilação, pois, é a redução a outra civilização de um grupo humano mais ou menos numeroso de indivíduos, o qual abandona todos os laços culturais anteriores, adquirindo novos que lhes são transmitidos pelo grupo humano em contato com o qual ele é posto [...]. Do cruzamento do estrangeiro com o paulista resulta a homogeneização de duas mentalidades diferentes, ficando a exótica plasmada nos moldes da paulista que acaba prevalecendo. É o que se dá entre nós (Ellis Jr., 1934:84-85).

Tal qual exposta por Ellis Jr., o conceito de assimilação, concebido como fenômeno biológico-racial (além de cultural), sofreu no Brasil a influência de intelectuais que, ao final do século XIX e início do século XX, debateram obsessivamente a formação (de um tipo) nacional, influenciados pelas teorias eugenistas ${ }^{2}$. Tais teorias tomavam como premissa a desigualdade entre as raças e propugnavam sua classificação e hierarquização, entre os extremos de uma raça branca superior e uma raça negra inferior. Ademais, as teses do darwinismo social e da pureza racial difundidos até a Primeira Guerra Mundial condenavam a mestiçagem racial. Contudo, conforme argumentou Seyferth,

os cientistas brasileiros encontraram meios para contornar a visão negativa seguida pelo racismo para a mistura de raças ora classificadas como inferiores, ora como atrasadas: inventaram a tese do branqueamento e os mestiços "superiores"! [...] Nos termos da sua versão "científica", [...] o branqueamento da raça era visualizado como um processo 
seletivo de miscigenação que, dentro de um certo tempo (três gerações), produziria uma população de fenótipo branco [...]. Sendo assim, os imigrantes tinham um papel adicional a exercer: contribuir para o branqueamento e, ao mesmo tempo, submergir na cultura brasileira (Seyferth, 1996:48-49).

Por outro lado, a massa de trabalhadores nacionais era pensada como racialmente inferior, embora a esta fosse atribuída o importante papel de transformar imigrantes em brasileiros.

Assim é que Silvio Romero, nos albores do século XX, criticou o descaso da monarquia com a composição étnica da população nacional, ao mesmo tempo em que defendeu a ideia de misturar migrantes nacionais com estrangeiros em todas as regiões do país ${ }^{3}$, colocando-os lado a lado, para o trabalho, de modo a educar os primeiros e abrasileirar os últimos. Adepto da mestiçagem, Romero - e, após ele, outros - fizeram um uso muito particular das teorias raciais em voga nos países civilizados: de um lado, como mostraram Schwarcz e Queiroz (1996:172-174), naturalizou hierarquias sociais, políticas e econômicas com base na ideia de raça; de outro, rejeitou que a mestiçagem gerasse indivíduos degenerados, piores ainda que as ditas raças inferiores ${ }^{4}$.

Tal debate é anterior ao conceito de assimilação, tal qual definido por Robert Park e outros expoentes da Escola de Chicago, mas certamente influenciou o uso do conceito aqui no Brasil, a partir do final dos anos vinte. Além de Ellis Jr., pode-se também tomar como exemplo Oliveira Vianna (que por sinal foi aluno de Silvio Romero), cujas teses sobre o caldeamento ou fusão de raças conjugam dos mesmos pressupostos de hierarquia racial e primazia branca, ao propor que, quando duas raças desiguais são colocadas em contato, as menos fecundas são absorvidas ou dominadas: uma gera os senhores e a outra os servidores (Vianna, 1933a:154-155). Em Raça e Assimilação, publicado originalmente em 1932, desenvolve uma série de cálculos sobre coeficientes de homogeneidade, coeficientes de fusão e índices de fusibilidade para aferir o que denomina melting pot nacional. Em suas palavras, o objetivo seria dotar de "bases científicas para a solução de alguns problemas mais urgentes e imperativos, como os que se prendem à formação da nossa nacionalidade [...]. Por exemplo: o problema da mestiçagem das raças. Ou o da seleção eugênica da imigração. Ou o da distribuição racional das etnias arianas [sic] segundo o critério da sua maior ou menor adaptabilidade às diversas zonas climáticas do país" (Vianna, 1933b:89-90). 
Neste livro, Oliveira Vianna insurge-se contra as teses de igualdade das raças que começavam a tomar corpo nos anos vinte 5 . No meio intelectual nacional, ele talvez possa ser apontado como um dos últimos propagadores do racismo científico como princípio de explicação do Brasil e da necessidade imperiosa de promover a assimilação racial.

De fato, como observou Skidmore (1976:183-192), as explicações que tomavam as características raciais como responsáveis pelas mazelas do país passaram a ceder lugar, a partir já da eclosão da Primeira Guerra Mundial ${ }^{6}$, para a relação homem-meio, tanto no que se refere aos males causados por condições de vida insalubres, como advogavam os próceres do movimento sanitarista, como pelas apreensões concernentes a reformas sociais e, sobretudo, à necessidade de educação do trabalhador nacional - tal como era defendido por escritores como Monteiro Lobato ou por cientistas como Roquete Pinto. O próprio Lobato, que antes condenara seu personagem Jeca Tatu em função de seu hibridismo racial, mudara de opinião, creditando-lhe seus infortúnios às epidemias que o flagelavam. "Jeca Tatu não é assim, ele está assim", decretou em Urupês ${ }^{7}$.

Em São Paulo, a própria revolução cultural do modernismo trazia em seu bojo a valorização de uma identidade nacional. Stepan, em obra recente, notou que, "por volta da década de 1920, a classe educada estava cada vez mais 'assimilacionista' no discurso público, ainda que privadamente e em suas relações sociais fosse racista e discriminadora" (Stepan, 2005:165). O pressuposto básico, por tanto tempo dominante, da perspectiva racista de que o sangue dos ex-escravos africanos representara um prejuízo ao desenvolvimento nacional, começara, enfim, a ser questionado. Ao mesmo tempo, entre os intelectuais, Roquete Pinto, Arthur Ramos e, mais tarde, Gilberto Freyre promoveram uma reinterpretação otimista do caráter nacional, destacando a herança negra e a mestiçagem no que elas poderiam aportar de positivo à nação.

Contudo, havia diferenças significativas entre eles. Para alguns autores, como Arthur Ramos, o tema do caldeamento e, portanto da assimilação (compreendida também como fenômeno racial), mantém-se ainda em sua obra Introdução à Antropologia Brasileira (1943/7), na qual dedica páginas e páginas à caracterização racial dos diferentes grupos (imigrantes inclusive) presentes no território nacional (Seyferth, 2004:13). Assim, conforme observou Stepan (2005:179-180), 


\section{Oswaldo Truzzi}

embora as avaliações raciais tenham mudado, a estrutura do argumento eugênico - com sua ênfase nas diferenças biológicas como fatores-chave na composição de uma nação - não mudara. Poder-se-ia dizer que a 'miscigenação construtiva' era, por conseguinte, tanto um produto do racismo quanto seu reverso. O conceito havia estabelecido a raça biológica como o ponto crucial da nacionalidade e deixara, em alguns casos, legados institucionais duradouros na forma de leis de restrição à imigração influenciadas pela eugenia. A ênfase dos eugenistas na homogeneização através do amalgamento biológico era uma mistificação das realidades políticas e sociais de suas sociedades muito pobres tanto quanto a teoria inversa que alertava contra a heterogeneidade racial e a degeneração híbrida.

Assim, muito embora a partir de então crescentemente desacreditado por parcelas da intelectualidade que não se fiavam à tese do determinismo biológico - e Gilberto Freyre e Roquete Pinto, ambos bastante influenciados por Franz Boas, aqui são os nomes maiores -, o ideário assimilacionista ainda repercutiu diretamente na agenda política do novo regime instaurado nos anos trinta. Mas o fez buscando instaurar uma consciência homogênea de nacionalidade disposta a eliminar ou ao menos aplainar disparidades étnicas. Nessa medida, não tratava de amaldiçoar a herança negra ${ }^{8}$, mas, sobretudo, de proteger supostas ameaças externas representadas por grupos alienígenas cujas características físicas e culturais poderiam por em risco o processo de homogeneização racial e cultural do país. O que se desejava, portanto, não era uma intervenção cultural do estrangeiro, que pudesse ameaçar a língua portuguesa, a hegemonia católica e, de modo geral, a cultura latina. Daí serem alguns grupos mais desejáveis que outros, justamente porque mais assimiláveis (Ramos, 1996).

O foco passava a ser garantir o processo de assimilação para quaisquer grupos que pretendessem se fixar ou que já haviam se fixado no país. Prova disso são os debates que presidiram a Constituinte de 1934 e a adoção do regime de cotas migratórias, cujos efeitos restringiram com maior intensidade o fluxo de japoneses, tidos à época como menos assimiláveis, e também de judeus perseguidos pelo nazismo. Tais apreensões seriam confirmadas poucos anos depois, na própria definição e rumos que tomou a campanha de nacionalização durante o Estado Novo, arquitetada por funcionários do governo que difundiam suas ideias na Revista de Imigração e Colonização, publicada pelo Conselho de Imigração e Colonização. Entre as atribuições deste órgão - instituído 
em maio de 1938 e diretamente subordinado ao Presidente da República - constavam explicitamente: "propor ao Governo as medidas que convenham ser adotadas, a fim de promover a assimilação e evitar a concentração de imigrantes em qualquer ponto do território nacional", além de "estudar os problemas relativos à seleção imigratória, à antropologia étnica e social, à biologia racial e à eugenia" ${ }^{\prime}$. Tais medidas alçaram o combate aos ditos "enquistamentos étnicos" e o imperativo do abrasileiramento compulsório ao nível de política de estado, forçando o fechamento de associações, escolas e periódicos ligados a instituições étnicas (Seyferth, 1999:199-228).

\section{ASSIMILAÇÃO COMO EXPRESSÃO EXCLUSIVA DE MUDANÇA CULTURAL}

Somente com o fim da ditadura varguista e consequente redemocratização, o termo assimilação no Brasil foi objeto de uma utilização mais acadêmica e menos influenciada pelos preceitos de uma política de governo preocupada com a questão da definição de um povo para uma nação em formação. A crise dos anos trinta, as restrições impostas à imigração estrangeira pela Constituinte de 1934 e, em seguida, a eclosão do segundo conflito mundial arrefeceram o ímpeto migratório vindo do exterior e, por conseguinte, o debate acerca do tema com tons nacionalistas. Os próprios horrores do nazismo, revelados com a derrota da Alemanha, contribuíram para colocar o tema da assimilação, visto sob uma perspectiva racial, na berlinda. Nessa segunda fase, a partir do pós-guerra, os meios acadêmicos trataram de interpretar a experiência de recepção de imigrantes internacionais sob uma perspectiva menos assimilacionista (ideológica e racialmente falando), ainda que se valendo do termo assimilação. A esse respeito, o autor seminal é Emilio Willems, que tratou do conceito com maior rigor teórico e metodológico em seus dois livros sobre alemães no sul do Brasil publicados em 1940 e 1946. Vale a pena reproduzir o verbete assimilação constante do Dicionário de Sociologia, de sua autoria, publicado em 1950 (Willems, 1950:8):

conjunto das mudanças de ordem psíquica a que estão sujeitas as pessoas que se transferem de uma determinada sociedade para outra, culturalmente diversa. Praticamente essas mudanças consistem na obliteração, substituição e modificação de hábitos (modos de sentir, pensar e agir) anteriormente adquiridos. Os novos hábitos exteriorizam-se em forma de atitudes total ou parcialmente diferentes de atitudes anteriores. É óbvio que as atitudes novas surgem condicionadas a elementos 


\section{Oswaldo Truzzi}

culturais novos ou diferentes. Grau e ritmo de assimilação são determinados sobretudo pelas diferenças ou semelhanças culturais, pela frequência e espécie de contatos que se estabelecem entre pessoas culturalmente diversas. Outro fator importante representam as condições sociais em que ocorrem os contatos. Geralmente, a assimilação é acompanhada de conflitos mentais cuja intensidade varia em razão dos antagonismos que se observam entre os padrões de comportamento da sociedade antiga e da nova. Enquanto duram esses conflitos, a pessoa é marginal. A assimilação não exige a substituição de todos os hábitos anteriormente adquiridos. As necessidades básicas dos homens são as mesmas e as culturas criadas para sua satisfação apresentam semelhanças fundamentais. Daí se pode inferir que, em qualquer hipótese, uma parte das experiências anteriores pode ser utilizada para fazer os reajustamentos que a nova situação exige. A assimilação compreende exclusivamente hábitos, quer dizer, traços que a pessoa humana adquire em interação com seus semelhantes. Por isso, a assimilação nada tem que ver com fatores biológicos como nascimento, ascendência ou "san-

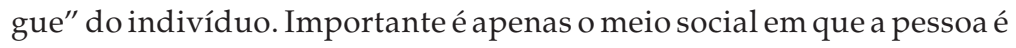
educada.

Portanto, trata de definir o conceito de assimilação como:

a) atributo de mudanças na personalidade de indivíduos expostos a situações culturais distintas (ele reservará o conceito de aculturação (Willems, 1950:1-2) para tratar das mudanças na cultura de dois ou mais grupos em contato direto e contínuo);

b) que varia em grau e ritmo, segundo a distância cultural, frequência e tipo de contato;

c) que pode gerar ainda conflitos mentais (e daí marginalidade individual);

d) que apresenta caráter exclusivamente cultural, e não racial ou biológico, como comumente interpretavam os defensores do chamado melting pot nacional ${ }^{10}$;

e) que pode ser de natureza bilateral, ainda que prevaleça a influência da sociedade inclusiva sobre o grupo minoritário.

Como ressaltou Seyferth, os trabalhos de Willems têm muitos méritos, mas podem ser criticados por incorrerem a psicologismos em voga na época, como o conceito de indivíduo marginal ou desajustado, enredado em uma cultura híbrida que, ao longo do tempo e de uma geração à outra, tenderia inevitavelmente a se desfazer. "Todos os indícios de 
existência de uma ideologia étnica e de valores culturais próprios (...) são minimizados como resíduos ou sobrevivências, ou resistências a uma assimilação inarredável!" (Seyferth, 1988:31). Seu trabalho foi muito influente para toda uma geração de antropólogos e sociólogos empenhados em descrever as mudanças socioculturais experimentadas ao longo da experiência de diferentes grupos migratórios. Autores como Saito (1961), Saito e Maeyama (1973), Vieira (1973), Rattner (1977), Azevedo (1981), Schaden (1956), Diegues Jr. (1964) e Albersheim (1962), todos citados por Seyferth ${ }^{11}$, ao lado de outros, como Balhana (1958), recorrerão, de uma forma ou de outra, ao conceito de assimilação, até pelo menos o final dos anos setenta.

Em São Paulo, contudo, ocorreram diferenças importantes na própria cadeira de Antropologia da Universidade de São Paulo, onde Willems fora catedrático entre os anos de 1941 e 1949. Aí os conceitos de assimilação e aculturação, tal qual definidos por Willems, foram inicialmente empregues nos assim chamados estudos de comunidade. Havia um traço comum entre tais estudos e os de grupos migratórios, já que estes normalmente eram capturados em sua inserção em uma determinada comunidade, mais comumente no meio rural ${ }^{12}$. O próprio Willems, após escrever sobre os alemães, havia publicado um estudo pioneiro sobre Cunha, no Vale do Paraíba, imprimindo aqui pioneiramente o formato dos estudos de comunidade ${ }^{13}$. Após a saída de Willems, a cadeira foi então ocupada provisoriamente por Egon Schaden, até meados dos anos 60, que continuou a empregar o conceito de aculturação, sobretudo no estudo de grupos tribais (Pereira, 1994) ${ }^{14}$.

Contudo, as assistentes mais jovens da cadeira de Antropologia, Eunice Durham e Ruth Cardoso, pautaram suas produções acadêmicas iniciais por um relativo distanciamento dos estudos de comunidade e aculturação. De fato, embora ambas também tenham se dedicado a estudar grupos migratórios e efetivamente tenham utilizado o conceito de assimilação, o fizeram sob uma perspectiva que já ecoava as disputas institucionais na própria Universidade de São Paulo (USP) entre as cadeiras de Sociologia I, conduzida por Florestan Fernandes, e a de Antropologia. Conforme apurou Corrêa (1995:61),

Ruth observa que a tese dela e a de Eunice deviam muito mais à influência geral de Florestan Fernandes e de Gioconda Mussolini, a partir de suas críticas derivadas do funcionalismo inglês à ideia de aculturação, então hegemônica na Antropologia da USP, do que à orientação de Egon Schaden (...). "Os estudos de comunidade e os estudos de acultu- 


\section{Oswaldo Truzzi}

ração representavam tudo o que estávamos renegando: o foco na vida rural, a ideia da integração. Nós tínhamos interesse na mudança social, nos processos de urbanização... era uma análise mais sociológica" (Ruth Cardoso, depoimento). O trabalho de Eunice Durham já sinalizava a partir do seu título ( $A$ Caminho da Cidade) essa transição ${ }^{15}$.

A crítica aos estudos de comunidade pautava-se, de modo geral, por duas vertentes: em primeiro lugar, alegava-se que tais estudos desdenhavam os processos históricos que conduziram às realidades sociais analisadas $^{16}$. Em segundo lugar, criticava-se o isolacionismo imposto pelo recorte da comunidade e a ausência de foco nos vínculos desta com a sociedade mais ampla, na qual se insere e da qual depende. Pode-se tomar, a esse respeito, o comentário de Ruth Cardoso sobre um estudo dos italianos em um bairro de Curitiba, realizado por Altiva Pilati Balhana, nos moldes dos estudos de comunidade. Após elogiar a riqueza descritiva do trabalho, emenda: "o que falta é a tentativa de explicar o processo de assimilação, de esclarecer como funcionam os padrões culturais europeus e como são abandonados ou modificados" (Cardoso, 1961). Ou ainda, a apresentação de Antonio Cândido à sua obra Os Parceiros do Rio Bonito:

"não é um 'estudo de comunidade', no sentido hoje corrente, sobretudo entre americanos e ingleses. Não pretendi levantar sistematicamente os diferentes aspectos de determinado agrupamento, englobando todo o seu sistema institucional numa visão completa e orgânica. Depois de bastante hesitar, rejeitei esse ponto de vista, em parte pelo que tem de estático e convencional - levando-nos quase sempre a encarar os traços de uma dada realidade sociocultural como algo que, para usar velha expressão caipira, 'deverá de ser assim mesmo'. Por outras palavras, o estudo de comunidade, em seu corte descritivo mais frequente, me pareceu comprometer no pesquisador o senso de problemas" (Cândido, 1982:19-20).

Tal qual observaram Peixoto e Simões (2003:401), ao analisar os primeiros anos da Revista de Antropologia, "os balanços e comentários críticos realizados sobre os 'estudos de comunidade' - elaborados de formas diferentes e a partir de lugares distintos - parecem bater numa mesma tecla: o risco do encapsulamento da comunidade pela desconsideração de seus vínculos com a sociedade mais ampla e com a história". 
A que concepção de assimilação recorrem Durham e Cardoso para se afastarem do modo como esta foi empregue nos estudos de comunidade? Durham esclarece que utilizou o termo assimilação no mesmo sentido que Eisenstadt (1954) empregou o termo absorção. Tal noção abrange, simultaneamente, a aculturação, a dispersão étnica e o ajustamento individual ${ }^{17}$. Nesse processo, a autora enfatiza como a integração do imigrante esteve associada às oportunidades de ascensão criadas pela transformação da sociedade mais ampla. Nessa concepção, a noção de assimilação do imigrante encontra-se ancorada a noções mais dinâmicas de mobilidade social e de mudanças na sociedade que o inclui, pautas estas um tanto distantes dos estudos de comunidade tradicionais ${ }^{18}$. Em seus próprios termos, "para realizar o objetivo do trabalho assim definido, não podíamos nos restringir à análise dos fenômenos no âmbito estritamente local. Descalvado não é um sistema isolado. A sua história, como a história de seus imigrantes, só pode ser entendida como manifestação de tendências que caracterizam a sociedade global na qual ela se insere" (Durham, 2004:80).

Do mesmo modo, no caso de Cardoso, o próprio título de seu trabalho, "Estrutura familiar e mobilidade social; estudo dos japoneses no Estado de São Paulo", denota o compromisso da autora em realçar os processos de mobilidade a partir de uma crítica ao conceito de aculturação.

“A realidade do contato sociocultural só pode ser apreendida e sua ex-
plicação só será concreta se levar em conta um conjunto de dimensões
(entre as quais a cultural é fundamental) que devem ser empregadas na
interpretação do processo, reproduzindo teoricamente a unidade do
real. O conceito de aculturação não facilita esta tarefa porque privilegia
os traços culturais e supõe uma dinâmica que lhes é própria" (Cardoso,
1972:172).

A partir dessa crítica, a autora dispensa o uso do conceito de aculturação e, ao invés de assimilação, prefere utilizar o termo integração:

"o processo de integração do imigrante japonês é caracterizado neste trabalho, por um lado, por sua mobilidade social e, por outro, pela diminuição da distância cultural entre ele e o conjunto da sociedade, isto é, pela menor utilização de sistemas expressivos próprios. A mobilidade é importante porque os japoneses emigraram para o ocidente aceitando voluntariamente uma posição (talvez a mais baixa) na hierarquia das classes sociais. Não há exclusão étnica, como em outras situações 


\section{Oswaldo Truzzi}

de contato, e, com maiores ou menores obstáculos, dependendo do país, os imigrantes se situam dentro do sistema social como membros de uma classe. Sua posição na sociedade que o recebe está dada dentro do sistema de classes. É, portanto, dentro da estrutura existente e em transformação que o imigrante procura mudar de posição e mede seu progresso. Buscando ascensão, primeiramente como grupo e, depois de dado o primeiro passo, como indivíduo, é que os japoneses aspiram melhores posições. É de notar, entretanto, que a partir do momento em que age como indivíduo, o imigrante deixa de distinguir-se dos demais brasileiros de sua mesma classe social. Sua dissolução como etnia significa sua absorção como membro de uma classe, o que constituiria sua integração total" (Cardoso, 1972:175-176).

Seria injusto afirmar que os autores mais comprometidos com o conceito de aculturação utilizado, sobretudo, nos estudos de comunidade, tenham ignorado as relações de mão dupla entre mobilidade social e assimilação. O próprio Willems (1946:575) já observara o quanto a mobilidade social, favorecida por uma inserção urbana (em contraste com o meio rural), facilitara a assimilação e, pelo lado inverso, como esta constituía condição essencial à ascensão social e participação política. Entretanto, tanto Durham como Cardoso procuraram demarcar suas distâncias em relação ao conceito de aculturação tal qual empregue nos estudos de comunidade ${ }^{19}$. Nesse sentido, como já se ressaltou anteriormente, ambas seriam bastante influenciadas por uma perspectiva sociológica, já então dominante. Como fez questão de enfatizar Cardoso (1972:176) na conclusão de seu livro: "no interior das distinções de classe é que operam as identificações étnicas, estabelecendo novos recortes".

\section{ASSIMILAÇÃO EM BAIXA}

De qualquer modo, mesmo levando em conta as diferenças de contexto e ênfase acima apontadas, entre todas as concepções anteriores havia um traço comum: a de que a assimilação (ou outro termo equivalente) constituía, de uma forma ou de outra, um processo inapelável. Assim sendo, quaisquer traços culturais remanescentes de um grupo eram interpretados como indícios de uma assimilação ainda incompleta em direção a um padrão dominante. Nessa concepção, não havia espaço para a afirmação de uma cultura étnica que vai se modificando, entendida como construção historicamente determinada e iterativamente negociada, por solicitações tanto internas ao próprio grupo quanto ex- 
ternas da sociedade mais ampla. Para dar conta disso, começou então a se firmar o conceito de identidade étnica - ou etnicidade - nos estudos migratórios, simultaneamente ao progressivo abandono do conceito de assimilação.

A mudança de paradigma ocorreu antes nos Estados Unidos do que aqui, e sob uma forma que adverte o quanto as discussões sobre incorporação de imigrantes sempre se encontram social e historicamente ancoradas sobre as conjunturas enfrentadas pelas sociedades receptoras. Conforme observou Kazal, o apogeu do conceito de assimilação ocorreu ao longo dos anos cinquenta e início dos anos sessenta ${ }^{20}$, como reflexo da necessidade gerada pela Segunda Guerra Mundial de unidade nacional e da tendência no pós-guerra de interpretar a história norte-americana mais como uma narrativa de consensos, do que de conflitos. Em contraposição, toda a movimentação social do final dos anos sessenta, acompanhada das reivindicações sobre os direitos de afirmação de grupos minoritários, favoreceu estudos focados na persistência étnica, questionando frontalmente o paradigma da assimilação e a noção de uma referência cultural anglo-americana em direção à qual todos deveriam se aproximar (Kazal, 1995). A obra que assinala a mudança de tom, defendendo a persistência de identidades étnicas na sociedade americana foi a de Glazer e Moynihan (1963:v), que escreveram, em meados dos anos 1960: "the point about the melting pot (...) is that it did not happen". Surgia assim uma nova perspectiva - de avaliar os diversos grupos imigrantes e de reinterpretar a história de cada um deles - que endossava as teses do pluralismo cultural emergente, também às vezes tratado de modo genérico como multiculturalismo ${ }^{21}$.

O debate, como era de se esperar, repercutiu, embora tardiamente, na literatura nacional. Mas a passagem, de um paradigma a outro, não foi brusca, e sim mediada por aproximações. Assim é que Cardoso (1972:177), atenta às insuficiências do modelo anterior, na conclusão de seu livro, pôde escrever:

a identidade étnica é uma forma de estabelecer contrastes e separar o "nós" dos "outros", enfim, situar o grupo dentro do conjunto de outros que compõem a sociedade. Esta identificação indica a percepção da situação de contato e leva à utilização e ordenação de categorias culturais particulares que fundamentam a "consciência étnica". O objetivo do antropólogo é, na medida do possível, compreender as significações particulares que este grupo cria e o modo como as utiliza. Em outras pa- 
lavras, o grupo étnico manipula formas próprias de expressão que poderíamos chamar de "ideologia étnica".

Na opinião de Seyferth (2004:18), a mudança de orientação teórica foi mais perceptível nas abordagens influenciadas por Eisenstadt que, embora tenha dado maior importância à socialização e à transformação dos valores dos grupos primários, também observou que os processos de absorção dos imigrantes, ou a evolução de uma nova estrutura institucional, não eram suficientes para obliterar as distinções grupais, desenvolvendo-se uma estrutura pluralista em que emergem identidades separadas ${ }^{22}$.

De qualquer modo, se, até os anos oitenta no Brasil, a noção de assimilação (ou de aculturação, em sua variante antropológica) havia dominado o campo dos estudos migratórios, a partir de então, vários autores passaram a criticá-la devido a impropriedades em sua utilização e a descortinar um novo campo de possibilidades ao se revalorizar a experiência específica de cada grupo étnico, agora fora do paradigma assimilacionista. Seyferth (1988:33), por exemplo, analisando o significado da pertinência étnica teuto-brasileira, concluiu: "a cultura original foi transformada e certos valores, ideologias e instituições de caráter étnico desapareceram ou foram reelaboradas; mas critérios de distintividade usados para marcar a identidade étnica persistem apesar da assimilação." Na mesma linha, Fausto (1991:38) observou que "a noção de pluralismo cultural tem ainda a vantagem de não estabelecer uma constelação onde se localiza uma grande estrela - a sociedade nacional - para a qual todas as outras se dirigem, em ritmo mais ou menos acelerado. As relações são vistas de um modo mais complexo e não são redutíveis simplesmente à polaridade nacional/estrangeiro".

Truzzi, ao generalizar a partir do estudo das trajetórias dos sírios e libaneses em São Paulo, concluirá:

para se apreender a diversidade de apelos e de alternativas trilhadas pelos imigrantes, não é possível se trabalhar com uma perspectiva assimilacionista que nos conta uma história unidimensional, desenrolada entre os polos de um passado de tradições deixadas e de um futuro de integração na nova pátria. Não existiram nem caracteres culturais importados de modo fixo, nem abrasileiramento (ou apaulistanização), no sentido tantas vezes subjacente às análises sobre imigrantes. A pluralidade de combinações entre a herança cultural e as interações mantidas entre grupos e subgrupos étnicos e a nova sociedade constitui um 
processo muito mais rico e contradiz a noção de um padrão dominante em direção ao qual esses grupos tenderiam a se aproximar com o tempo. Os imigrantes não necessariamente foram "assimilados", mas construíram relações sociais absolutamente originais como estratégias de sobrevivência na nova terra. Abandona-se, assim, a noção de grupo étnico como a-histórico, imutável, e sua história pode ser contada, não como um dado, mas como um processo sujeito a idas e vindas, onde atuam forças centrífugas e centrípetas (2008a[1993]:281).

Seguiu-se então uma profusão de estudos que ressaltaram a especificidade das trajetórias e a revalorização das diferenças culturais de cada grupo étnico: italianos, espanhóis, portugueses, japoneses, sírios e libaneses, alemães, judeus etc. Houve ganhos evidentes nesse novo olhar, pois tal movimento de revalorização étnica, que - diga-se de passagem - coincide com a crescente busca pelo reconhecimento de cidadania estrangeira entre brasileiros descendentes de imigrantes, vem, de fato, ensejando uma série de novos estudos que promovem uma releitura das trajetórias dos grupos imigrantes que chegaram ao país. Traços culturais remanescentes, próprios a cada grupo, que antes eram vistos ora com preocupação, ora como resquícios culturais marginais de uma assimilação inarredável, passaram a ser então interpretados sob uma ótica de resistência cultural ou de afirmação de uma identidade étnica legítima, constitutiva mesmo de uma sociedade que hoje busca eleger a diversidade e a pluralidade étnica (e racial) como valores.

Porém, como já assinalou Fernando Pessoa, tudo são maneiras de ver e uma maneira de ver é também uma maneira de não ver. Assim, o foco centrado nas comunidades étnicas, nos lugares de concentração étnica ou nas próprias organizações étnicas colocou na penumbra a ocorrência de processos sociais mais abrangentes, entre eles a questão de como tais grupos, de uma geração para outra, se integraram ao tecido social, seja despojando-se de parte de seus marcadores étnicos, seja habitando em bairros da capital ou em cidades do interior sem características étnicas, seja incrementando índices de exogamia, seja formando comunidades, sociabilidades e desfrutando de valores nos quais o crivo era mais racial ou por classe do que étnico, seja renegociando e redefinindo estas próprias categorias étnicas e raciais.

De alguma forma, o foco sobre a pluralidade étnica e, por consequência, na formação, persistência, transformação e relevância de identida- 
des culturalmente demarcadas, foram e ainda são temas tão recorrentes que, aliados ao criticismo associado ao modelo clássico de assimilação, acabaram por eclipsar e descartar toda uma problemática definida sobre modelos de incorporação de imigrantes, avaliados sob uma perspectiva intergeracional, às sociedades de recebimento. É sob essa perspectiva que se apresenta hoje uma recuperação do conceito de assimilação em novos moldes.

\section{RECONCEITUAR O PROCESSO DE ASSIMILAÇÃO}

Nos Estados Unidos, no início da década passada, um artigo assinado por Roger Brubaker (2001:533-534) reconhecia que "a virada diferencialista" dava sinais de esgotamento e havia atingido uma espécie de turning point, ao mesmo tempo em que especulava sobre o retorno do conceito de assimilação, ainda que reformulado sob novas bases: "o que 'retornou' não foi a velha, analiticamente desacreditada e politicamente condenada compreensão de assimilação, mas outro entendimento analiticamente mais complexo e normativamente defensável $^{\prime 23}$. Dois anos depois, o conceito de assimilação foi definitivamente revisitado nos Estados Unidos a partir da influente obra Remaking the American Mainstream: Assimilation and Contemporary Immigration, de Richard Alba e Victor Nee, publicada originalmente em 2003. O lançamento do livro ensejou uma série de discussões e reavaliações a respeito do uso do conceito de assimilação na interpretação de como levas imigratórias são incorporadas às sociedades que as recebem.

Nele, os autores defendem que o conceito de assimilação, depurado de seus maus usos, constitui-se no paradigma mais apropriado, não somente para interpretar as imigrações históricas que a nação americana recebeu, mas também os fluxos contemporâneos. Ao redefinir assimilação e ao contrapor o conceito, agora revisto, com outros enfoques alternativos - como o do pluralismo cultural e o do transnacionalismo o livro, já em si polêmico por sua ambição, foi, no entanto, muito bem recebido pela crítica especializada, gerando apreciações positivas entre sociólogos e historiadores da imigração (Massey, 2004, Barron, 2004; Bean e Stevens, 2004; “Symposium”, 2004; Hao, 2005).

É impossível retomar neste artigo todos os argumentos desfilados pelos autores, mas o ponto central é a retomada do conceito em novas bases, alijado de suas conotações espúrias que, segundo eles, deturparam-no e condenaram-no. Assim, Alba e Nee argumentam que o con- 
ceito de assimilação, tout court, continua a ser relevante para explicar a incorporação de imigrantes à sociedade, ainda que esta não constitua a única possibilidade.

Tomando por base o caso americano, os autores defendem que, embora as identidades étnicas e raízes culturais possam ter sido valorizadas e celebradas, a chamada etnicidade tornou-se, com o tempo, um traço menos decisivo para influir nas trajetórias de vida. Ao contrário, Alba e Nee defendem a contínua relevância da assimilação, desde que se proceda a uma reavaliação do conceito, de modo a evitar o etnocentrismo implícito a ele associado. Buscam por isso construir uma teoria da assimilação que especifique mecanismos causais e, ao mesmo tempo, evite implicações normativas como a de que os imigrantes devem inevitavelmente ser assimilados ou implicações prescritivas, no sentido de haver um único modo ou ritmo de assimilação para todos os grupos. Assim, reconhecem a assimilação como um dos padrões possíveis de incorporação, ao lado de outras possibilidades, como o pluralis$\mathrm{mo} /$ transnacionalismo étnico (Basch, Glick-Schiller e Blanc-Szanton, 1994; Portes, 2004) ou a assimilação segmentada (Portes e Zhou, 1993) ${ }^{24}$. O mesmo tipo de argumento pode ser levantado em outras sociedades que também receberam (ou recebem) imigrantes, como foi o caso do Brasil (e do Estado de São Paulo, em particular), entre as últimas décadas do século XIX e o início da Segunda Guerra Mundial.

Contudo, em relação ao primeiro padrão, pluralista, enfatizam que as identidades étnicas e as raízes culturais podem ser celebradas no âmbito de cada grupo, de acordo com o que Gans (1979) denominou "etnicidade simbólica": uma forma de etnicidade vivenciada por indivíduos que podem "se sentir étnicos", ocasionalmente em família ou em atividades de lazer, mas que implica poucos compromissos na vida social do dia a dia. Para brancos, o conceito semelhante de "opções étnicas" (no sentido que vivências étnicas podem ser praticadas, mas não de modo obrigatório) foi cunhado pela antropóloga Mary Waters (1990). Alba e Nee argumentam que, no geral, a assim chamada etnicidade constitui um traço pouco decisivo para influenciar as trajetórias de vida de descendentes de imigrantes, ao contrário do que ocorria na geração de imigrantes propriamente dita, muito mais dependente de vínculos étnicos para se inserir no novo país, arrumar trabalho, local de moradia, se socializar, se reproduzir por casamentos, educar os filhos, atuar politicamente etc. Em relação ao transnacionalismo, argumentam que, ainda que este possa se constituir como um fenômeno im- 
portante para alguns grupos de imigrantes, dificilmente o será para a primeira geração nascida nos Estados Unidos, ansiosa por afirmar sua nacionalidade americana e ser aceita como tal. Assim, ainda que significativo para a geração contemporânea de imigrantes, quando observado sob uma perspectiva geracional, a vitalidade do conceito enfraquece.

Promovem então uma reavaliação do conceito de assimilação, procurando evitar o etnocentrismo implícito nas análises clássicas que estipulavam um padrão para o qual os imigrantes e seus descendentes deveriam transitar (no caso da sociedade americana, o que se convencionou chamar de WASP (White Anglo Saxon Protestant); no caso da brasileira, o europeu branco, preferencialmente católico). Nessa operação, os traços culturais dos grupos minoritários eram avaliados como inferiores; aprender um novo estilo de vida era necessário para a plena aceitação de tais grupos. Consequentemente, forjava-se implicitamente uma hierarquia de aceitabilidade racial e cultural (de ingleses protestantes a negros, no caso da sociedade americana; de brancos europeus a negros, no caso da nacional).

A partir do final da década de 1960, em uma época de movimentos sociais enfatizando direitos das minorias, de mudanças institucionais propugnando o reconhecimento e o direito de cada grupo a sua história, o conceito de assimilação foi condenado pela implicação de que grupos étnicos teriam que inevitavelmente ocultar seus próprios traços culturais. Os assimilacionistas foram criticados por não reconhecerem muitas vezes seu papel positivo. Criticava-se também a natureza unilateral do processo de assimilação proposta por autores como Gordon (1964): uma minoria deveria mudar completamente a fim de se assimilar enquanto a maioria (moldada pela cultura anglo-saxônica) permanecia incólume, como se não houvesse impacto das culturas étnicas sobre a cultura dominante.

Nos termos de Alba e Nee (2003:11), a assimilação deve ser compreendida e definida como

o declínio de uma distinção étnica e de suas diferenças culturais e sociais resultantes. Declínio significa nesse contexto que tais distinções se tornam menos relevantes, que as ocorrências para as quais elas são significativas diminuem em número, e que, portanto, elas produzem efeitos sobre domínios cada vez mais restritos da vida social. As origens étnicas dos indivíduos tornam-se cada vez menos relevantes em relação a 
membros de outro grupo étnico (tipicamente, mas não necessariamente, o grupo étnico majoritário), e que indivíduos de ambos os lados da fronteira se veem como cada vez mais parecidos, assumindo-se como similares em termos de algum outro fator crítico, como a classe social; em outras palavras, percebem-se mutuamente cada vez menos em termos de categorias étnicas, a não ser sob circunstâncias específicas ${ }^{25}$.

Em um extremo, observa-se uma situação (época) na qual as distinções étnicas são relevantes para todos os aspectos mais decisivos das trajetórias dos indivíduos pertencentes ao grupo - onde residem, com que tipo de emprego sobrevivem, com quem se relacionam, com quem se casam, o que aspiram, o que celebram etc. - ao passo que, em outro extremo, tais características étnicas retrocederam em importância, limitando-se a se fazerem presentes apenas em rituais familiares ou religiosos ocasionais.

Definida nestes termos, a assimilação não requer o desaparecimento da etnicidade, de modo que os indivíduos, por assim dizer "assimilados", não possam mais apresentar determinados marcadores étnicos. Não se faz necessário se despojar de ou negar traços culturais próprios ao grupo e concomitantemente a prender um novo estilo de vida necessário para a plena aceitação. Não se elege um modelo cultural particular - no caso americano, os WASPS - como padrão normativo ${ }^{26}$. A nova teoria proposta descarta tal tipo de etnocentrismo e rejeita a natureza unilateral do processo de assimilação presente no velho conceito. Tampouco compartilha da presunção de que a assimilação trará homogeneidade cultural onde antes reinava a diversidade.

Uma redefinição do conceito de assimilação, para ser viável - argumentam os autores - deve reconhecer que:

1) a etnicidade é essencialmente uma fronteira social, uma distinção que os indivíduos fazem em seu dia a dia, moldando ações e orientações mentais em relação a outros (Barth, 1998);

2) tal distinção é tipicamente contextualizada numa variedade de diferenças culturais e sociais entre grupos que emprestam às fronteiras étnicas significação concreta ${ }^{27}$, o que leva indivíduos a pensarem algo do tipo "eles não são como nós";

3) a assimilação, como uma forma de mudança étnica, pode ocorrer através de mudanças que se dão em ambos os lados da fronteira entre minorias étnicas e mainstream. 
Desse modo, processos de assimilação podem ocorrer não apenas via mudanças em um grupo que o tornam mais próximo de outro, mas também via mudanças nos dois (ou mais) grupos, que minimizam suas diferenças entre si. Em resumo, a assimilação advém muitas vezes de processos de convergência entre grupos. Ao contrário de uma concepção estreita de assimilação, na qual um grupo adota os traços culturais de outro, em um processo convergente o impacto de culturas étnicas minoritárias sobre o mainstream pode ocorrer pela ampliação do que é considerado comportamento normativo pelo mainstream, portanto elementos de culturas minoritárias podem ser incorporados à cultura central para criar uma cultura composta. Tal processo refaz o repertório de atitudes, valores, gostos e preferências, preconceitos, elementos de cultura popular, mitos etc, que passam a ser incrementalmente incorporados e refazem o mainstream.

E o que é o mainstream? É simples e pragmaticamente definido pelos autores como aquela parte da sociedade no interior da qual as origens étnicas e raciais apresentam um impacto menor sobre oportunidades ou trajetórias de vida dos indivíduos. Segundo os autores, os fundadores da escola de Chicago também enfatizaram uma concepção de mainstream vista como cultura composta decorrente da interpenetração de diversas práticas e crenças culturais. Esse sentido, porém, foi deixado de lado por outros autores, influenciados pelo funcionalismo de Parsons ${ }^{28}$, que canonizaram uma teoria da assimilação baseada em hierarquias de aceitabilidade racial e cultural - de protestantes ingleses a negros, no caso americano.

Neste ponto, fica evidente a importância da noção de fronteiras sociais entre grupos, em particular os processos de diluição e mudança, capazes de alterá-las. Após constatar que o mainstream muda quando elementos da cultura dos novos grupos são a ele incorporados ${ }^{29}$, Alba e Nee argumentam que a alteração de fronteiras ocorre segundo três tipos ideais:

1) Cruzamento de fronteiras (ou assimilação ao nível individual): ocorre quando alguém muda de um grupo para outro sem que a fronteira realmente mude. Por causa disso, tal possibilidade não altera a ordem relativamente estável da estratificação étnica ${ }^{30}$.

2) Obscurecimento de fronteiras: ocorre quando o perfil social de uma fronteira se tornou menos nítido, quando a clareza de uma distinção social se tornou mais nuançada. É a típica mudança invocada 
em misturas raciais (casamentos exogâmicos) em escala significativa, formando um grupo intersticial, que quebra a rigidez da divisão étnica ou racial. Tal possibilidade altera a ordem estável da estratificação étnica. Ocorre, por exemplo, com casais de diferentes origens religiosas: as fronteiras não desapareceram, mas os casais participam de ambas tradições religiosas. Nesse caso, apenas a situação de contato entre grupos não é condição suficiente. $\mathrm{O}$ fator-chave é o contato entre membros de diferentes grupos com status igualitário, mantido e produzido em uma escala apreciável por oportunidades socioeconômicas e residenciais disponíveis para cada um, às vezes apoiadas por mecanismos de cumprimento de direitos igualitários (proibição de segregação residencial, por exemplo). Se as interações ocorrem em uma escala substancial, o obscurecimento da fronteira tende a ocorrer, produzindo em membros de grupos distintos a percepção de que as diferenças são menores que as imaginadas. Grupos então que eram vistos em determinada época como etnicamente ou racialmente diferentes passam a ser percebidos como mais próximos ao longo do tempo.

3) Mudança de fronteiras: ocorre quando se trata efetivamente de uma relocalização da fronteira, de modo que grupos antes situados de um lado são agora incluídos de outro. Outsiders são assim, de uma época para outra, transformados em insiders.

Conforme já observado, tais categorias funcionam como tipos ideais: na prática, qualquer análise de um processo de assimilação envolve os três processos acima apontados.

Os autores investem então em deslindar os chamados mecanismos de assimilação - um repertório de processos, operando aos níveis individual, de grupo e institucional - que moldam as trajetórias de adaptação dos imigrantes e seus descendentes. Os mecanismos individuais e de grupo são configurados pelas formas de capital (social, econômico e educacional) que estes possuem, enquanto os mecanismos estruturais de assimilação se orientam por arranjos institucionais do estado, das empresas e do mercado de trabalho.

Assim, a assimilação, definida como a atenuação de distinções baseadas em origens étnicas, não se apresenta como resultado inevitável, universal, da trajetória de grupos minoritários. Os indivíduos ou famílias agem segundo as formas de capital (econômico, educacional, social etc.) de que dispõem e também segundo suas crenças culturais - cos- 
tumes, normas sociais, leis, ideologia e religião - que moldam percepções de autointeresse. Tomam suas decisões em um contexto de racionalidade limitada, confrontando riscos e informações disponíveis, de acordo com suas percepções de custos e benefícios. Se as decisões tomadas levam a um resultado benéfico, o grupo tende a reforçar tais escolhas.

Desse modo, para Alba e Nee, a assimilação aparece como um processo incremental, que ocorre a diferentes ritmos entre indivíduos e grupos. Tampouco pode ser caracterizado como um processo intencional, mas sim concebido como efeito cumulativo de decisões pragmáticas que os indivíduos e grupos tomam em determinados contextos institucionais historicamente variáveis. Tais decisões são operadas na maior parte dos casos no âmbito familiar, que é em última análise quem responde pela sobrevivência e busca da melhoria das condições de vida dos indivíduos $^{31}$. Não há um único mecanismo causal, mas sim um conjunto de mecanismos que varia segundo grupos étnicos e raciais, forjando modos de incorporação distintos, ora pautados por padrões iniciais de incorporação mais coletivistas (nos quais as famílias dependem inicialmente mais do grupo étnico) ou mais individualistas (nos quais a incorporação ao mainstream transita por fora do grupo). De modo geral, quando barreiras discriminatórias bloqueiam um padrão individual de mobilidade social, a assimilação, quando ocorre, depende de estratégias coletivas. O mais comum, porém, é se observar, no dia a dia dos grupos étnicos, um misto entre estratégias coletivas e individualistas. Pode-se pensar, por exemplo, no caso paulista, como os imigrantes europeus no pós-abolição se distanciaram coletivamente dos negros para ganhar aceitação social, impedindo casamentos e interações inter-raciais. Ou ainda, como alguns grupos de imigrantes investiram mais que outros em uma estratégia de inserção de seus filhos no mercado de trabalho como profissionais liberais.

Ao propugnar uma assimilação inevitável, os ideólogos do assimilacionismo ignoraram que, em alguns casos, o grupo étnico, ao dominar nichos econômicos, pode constituir a fonte de melhores oportunidades para empreendedores étnicos, diminuindo riscos e incrementando as chances de sucesso ${ }^{32}$. Além disso, o grupo pode prover modos não econômicos de contribuir para o bem-estar de seus membros, como prestar solidariedade e apoio a indivíduos com quem se compartilha um senso de ancestralidade comum. 
Para completar, os mecanismos que desencadeiam processos de alteração de fronteiras, que lastreiam a assimilação assim conceituada, não dependem unicamente da agência de indivíduos (ou, coletivamente, de grupos de indivíduos), mas também de processos estruturais e institucionais que oferecem (ou denegam) oportunidades. Entre eles, os mais importantes dizem respeito às políticas reguladoras do mercado de trabalho (que coíbem ou incentivam nichos ocupacionais), às políticas educacionais e culturais mantidas pelo Estado, às políticas públicas capazes de assegurar ${ }^{33}$ a extensão de direitos constitucionais a minorias étnicas e raciais (aumentando o custo da discriminação), e às mudanças de valores de modo geral na sociedade (como o declínio de ideologias racistas, ou a valorização da diversidade, por exemplo). Assim, a capacidade e a vontade de grupos estabelecidos como maioria em resistir e excluir recém-chegados podem retardar a assimilação. Ao contrário, o combate à discriminação e a afirmação de direitos civis para quaisquer grupos, independentemente de suas origens, tornam as fronteiras institucionais do mainstream mais abertas, favorecendo uma gradual assimilação. Também o crescimento econômico pode ser visto como condição estrutural para uma assimilação em grande escala, ao propiciar a abertura de novos espaços, o desenvolvimento de novos setores, de alguma forma incentivando imigrantes com vocação empreendedora ${ }^{34}$.

Temos então um conjunto de causas próximas, moldadas pelas formas de capital que indivíduos e grupos possuem, e outro conjunto de causas estruturais, expressas em políticas institucionais do Estado, dinamismo econômico e valores sociais. Da interação entre estas duas esferas, que variará de grupo para grupo, de lugar para lugar e de época para época, a assimilação, com seu ritmo específico para cada combinação, poderá surgir como uma das possibilidades de incorporação de minorias étnicas e raciais ao mainstream.

Desse modo, o esquema proposto é suficientemente flexível para acolher diferenças tanto no que diz respeito a trajetórias distintas de indivíduos (no interior de um mesmo grupo), quanto entre diferentes grupos étnicos ou raciais. Em ambos os casos, as trajetórias efetivamente desenvolvidas de incorporação dos imigrantes e de seus descendentes à nova sociedade serão bastante influenciadas pelas formas de capita ${ }^{35}$ que indivíduos e grupos possuem ao aportarem ao novo destino: qualificação da força de trabalho, escolaridade, experiência profissional (urbana ou rural) anterior ${ }^{36}$, vitalidade das redes de acolhimento 
étnico etc. Ao mesmo tempo, não se ignoram as influências do papel do Estado na formulação de políticas públicas e de outras características da chamada sociedade receptora.

Os autores em questão concedem que, embora os modelos de incorporação alternativos - pluralista/transnacional e segmentado - possam apresentar suas próprias esferas de validade, nenhum deles exclui a circunstância de que a assimilação jogou um papel central no passado e provavelmente também o fará no futuro com os novos imigrantes. Assim, apesar das críticas precisas recebidas dos pluralistas, argumentam que a vitalidade do conceito de assimilação não perdeu sua utilidade para iluminar e esclarecer as experiências dos imigrantes a longo prazo na nova sociedade.

Embora a obra de Alba e Nee tenha sido amplamente discutida e acolhida com entusiasmo nos meios acadêmicos norte-americano e europeu, infelizmente no Brasil - país que, entre os anos de 1880 e 1940, alinhou-se entre os três que mais receberam imigrantes do estrangeiro até agora tais discussões não reverberaram na pauta dos estudos migratórios, quer da época, quer atuais.

Do mesmo modo, na historiografia da imigração argentina, a rígida oposição entre assimilação e pluralismo como alternativas de interpretação da incorporação de imigrantes à sociedade nacional perdeu fôlego na última década. A própria fundação da sociologia acadêmica nesse país, por Gino Germani, fora originalmente tributária de uma concepção que atribuía à assimilação dos imigrantes um papel central, uma mediação necessária ao problema que de fato interessava a Germani: a transição da Argentina tradicional à Argentina moderna ${ }^{37}$. Assim, a afirmação da assimilação era necessária porque permitia designar ao imigrante europeu o papel principal de agente modernizador (Germani, 1987; Devoto, 1992; Jorrat e Sautu, 1992). A partir dos anos oitenta, no entanto, essa visão idílica em relação a uma assimilação precoce e bem-sucedida na sociedade argentina e, sobretudo, portenha, passou a ser crescentemente criticada a partir de estudos historicamente mais precisos que enfatizaram a baixíssima participação política dos imigrantes, o forte associativismo étnico, as altas porcentagens de retorno, a vigência de preconceitos, os limites à mobilidade social etc. Polarizou-se então um debate entre assimilacionistas e pluralistas, no qual o que estava em disputa não era propriamente se havia ocorrido ou não a assimilação, mas a que ritmos, segundo quais com- 
passos e intensidades diferentes dependendo do grupo, de sua época de chegada, segundo que dinâmicas regionais próprias etc., abrindo-se uma pauta distante de uma trajetória-padrão única de assimilação unânime e uniformemente trilhada ${ }^{38}$.

Pode-se agregar a tais considerações que os assimilacionistas enfatizaram mais os resultados do que os processos e que os pluralistas prestaram mais atenção às fases iniciais que às diferenças finais nos processos de incorporação dos grupos imigrantes à sociedade (Devoto e Otero, 2003). Por outro lado, é razoável supor que, pelo menos a curto prazo - e aqui os prazos são avaliados em termos de gerações (isto é, pelo menos para a primeira e segunda gerações) -, em nenhuma sociedade existe uma plena assimilação ou um pleno pluralismo. Ao contrário, estes deveriam ser encarados como tipos ideais, como instrumentos de análise teórica, como padrões que facilitam a comparação entre grupos distintos e entre sociedades receptoras distintas, e não como realidades absolutas e diretamente observáveis. Assim, também na sociologia histórica argentina, a polaridade entre partidários das perspectivas assimilacionista e pluralista arrefeceu e as apreciações por demais dicotômicas e generalistas a esse respeito abrandaram, cedendo lugar a estudos de natureza mais empírica, muitas vezes recortados regionalmente, que explorassem o que efetivamente ocorreu no que diz respeito às dimensões mais comumente exploradas em estudos do gênero: padrões ocupacionais, pautas matrimoniais, aglomerações residenciais, sociabilidades e inserção política dos diferentes grupos de imigrantes, vis-à-vis à sociedade nativa.

Da mesma forma, em artigo recente que analisa o caso uruguaio e, em particular, as estratégias matrimoniais de italianos, espanhóis e seus descendentes em três regiões deste país, Michael Goebel pôs em dúvida a noção de que assimilação e ascensão social, por um lado, e segregação étnica e exclusão socioeconômica por outro, caminhem paralelamente, tal como supuseram os assimilacionistas clássicos. Contudo, confirma, sob uma perspectiva de longo prazo, e por meio de uma variedade de caminhos, a importância decrescente do pertencimento étnico como fator determinante na vida social de imigrantes italianos, espanhóis e seus descendentes no Uruguai. Argumenta então este autor que "pluralismo étnico e assimilação, ao invés de se apresentarem como opostos irreconciliáveis, interagem de modo complexo, mas o fazem de maneira que em última análise resultam em um declínio, ainda que não no desaparecimento completo, da origem étnica como marca- 
dor identitário" (Goebel, 2010). Assim, após um longo período de desprestígio, o termo "assimilação" parece experimentar certa revalorização no mundo acadêmico anglo-saxão, especialmente nos Estados Unidos, ao mesmo tempo em que se procura reavaliar sua pertinência em sociedades platinas.

Na literatura nacional, contudo, tal reapreciação do conceito de assimilação ainda não chegou. O próprio uso do termo é condenado corriqueiramente como sinônimo de etnocentrismo e intolerância. No campo disciplinar da sociologia, da antropologia e da história das migrações no Brasil, o que hoje se assiste é a adoção - diga-se de passagem, muito bem vinda - de uma visão relacional do mundo social, incorporando-se o conceito de redes aos estudos migratórios. Assim, a inclusão de critérios interacionais (conteúdo, intensidade, duração e frequência de contatos), o problema da difusão da informação (para migrar, casar e obter emprego, por exemplo), a par de outras dimensões, testemunham o esforço (e o desafio) de como integrar dimensões relacionais a fatores estruturais clássicos (demográficos, econômicos e sociais), comumente presentes nas análises do tipo push-pull (fatores de atração e repulsão) nos estudos migratórios (Truzzi, 2008b; Martes e Fazito, 2010).

Não há nada, contudo, que procure reavaliar a experiência de recepção de imigrantes estrangeiros, tão decisiva na formação da população paulista e de outras regiões brasileiras, à luz desses novos desenvolvimentos teóricos ocorridos na última década. Sem pretender negar a enorme contribuição que estudos específicos aportaram para a elucidação e revalorização das identidades étnicas peculiares a cada grupo, não se pode deixar de reconhecer, sobretudo quando analisada sob uma perspectiva geracional e macro, a prevalência, a longo prazo, de um processo de assimilação no contexto nacional, desde que entendido sob a nova ótica proposta por Alba e Nee, de declínio progressivo (e multilateral) de uma distinção étnica e de suas diferenças culturais e sociais resultantes.

Desse modo, é preciso situar a experiência nacional de incorporação de imigrantes frente ao que vem sendo debatido em outras sociedades receptoras, como os Estados Unidos, a Argentina e o Uruguai. Além disso, a própria experiência nacional é extremamente diferenciada: o que ocorreu no Estado de São Paulo ${ }^{39}$ também merece ser confrontado com a experiência de incorporação de imigrantes em outros estados da Fe- 
deração, como os da região sul e o Espírito Santo, nos quais também houve imigração expressiva, mas não vigeu o regime de colonato característico da economia cafeeira de São Paulo.

\section{CONCLUSÕES}

Expurgado de seus elementos apócrifos, o conceito de assimilação vem recuperando terreno na análise de processos migratórios, sem que isso signifique abrir mão do conceito de etnicidade. Como precisamente observou Giralda Seyferth (2004:23) referindo-se aos autores que trabalharam no paradigma vigente até os anos 1980, assimilação (ou aculturação), por um lado, e etnicidade, por outro, não são fenômenos mutuamente excludentes.

É falacioso considerar esta abordagem teórica imprópria face aos criticismos advindos dos conceitos de identidade e etnicidade que reconfiguraram as análises de contextos multiculturais ou multiétnicos (...). Torna-se necessário lembrar que esses pesquisadores [referindo-se aos que trabalharam com o conceito de assimilação] estavam mais interessados nos processos de mudança social e cultural que conduzem à integração do imigrante no país de acolhida, e menos preocupados com a pluralidade cultural e étnica do Estado-nação imigrantista e assimilacionista. [Ou ainda:] o período que alguns analistas da colonização assinalam como início do processo de assimilação (ou de aculturação) dos imigrantes é também o da formação das identidades étnicas - processos que, sem paradoxos a considerar, são concomitantes, desde que não se perceba o primeiro como tendo sentido único e irreversível (Seyferth, 2000a:149).

A reconceituação do termo assimilação sob as novas bases propostas por Alba e Nee abre a possibilidade de reconciliar estas duas perspectivas, sem incorrer aos etnocentrismos que o antigo conceito de assimilação implicava. A crítica ao antigo conceito, ainda que justa e producente do ponto de vista de fomentar uma grande quantidade de estudos sobre diversos grupos migratórios, de algum modo produziu o efeito de se "descartar a criança junto à água do banho". À luz da nova orientação do conceito proposta, etnicidade e assimilação não se apresentam como irreconciliáveis e a afirmação e reconhecimento do primeiro não implica necessariamente desqualificar a problemática da incorporação, a longo prazo, de imigrantes a um determinado tecido social. Como bem assinalou Fausto (1991:38), a adoção da primeira perspecti- 
va "não importa em negar o fato óbvio de que, nas condições de São Paulo, se deu um profundo inter-relacionamento entre a sociedade nacional e as várias etnias e destas entre si".

A ressignificação do conceito de assimilação proposta por Alba e Nee abre, pois, uma dupla agenda de trabalho. Do ponto de vista da sociologia histórica das migrações, importa reavaliar a experiência migratória dos diferentes grupos que acorreram às diferentes regiões do país (e especialmente ao Estado de São Paulo), sobretudo na época da imigração em massa, situada, grosso modo, entre 1880 e 1940, próximo à eclosão da Segunda Guerra Mundial. Na verdade, esse período se refere à chegada dos imigrantes, mas para dar plena consequência às formulações propostas por estes dois autores, seria necessário ir pouco mais além, investigando também o que aconteceu com a primeira geração nascida no Brasil, em particular o modo como cada grupo, com suas características próprias (época de chegada, inserção socioeconômica e backgrounds culturais distintivos), interagiu com distintas conjunturas decorrentes de políticas de estado (imigratórias, reguladoras do mercado de trabalho, ou de maior ou menor tolerância em relação a estrangeiros), e foi "assimilado," isto é, que processos presidiram a quebra de fronteiras, de modo bilateral, entre cada grupo e o restante da sociedade. Em outras palavras, como cada grupo ou segmento de grupo (por exemplo, localizado na capital, ou no interior, neste em zonas mais antigas ou mais novas, em áreas rurais ou urbanas) transitou de um regime onde o crivo étnico pautava as agendas culturais, de inserção econômica (trabalho) e de sociabilidade (associativismo, casamento, moradia etc.) para outro regime (mais pautado por critérios de classe) no qual aquele pouco interferia no cotidiano concreto dos indivíduos, a não ser pela remota alusão a uma origem comum.

Seria ingênuo, e por demais generalizante, supor que cada grupo ou fração deste, tenha experimentado o mesmo tipo de trajetória e enfrentado os mesmos dilemas, neste processo, independentemente dos atributos relativos às suas características próprias - isto é, de quando chegou e de uma certa estrutura de capitais que o singulariza -, em interação com o restante da sociedade e com as políticas de estado singulares a cada época. A respeito da relevância destas últimas, basta lembrar as mudanças decisivas concernentes às políticas migratórias nacionais ocorridas ao longo dos anos trinta. Tal agenda de trabalho não deve se esgotar na análise dos processos estruturais e institucionais envolvidos nesta "assimilação", mas também contemplar uma análise compa- 
rativa das formas de capital detidas por cada corrente étnica ao chegar ao Brasil. Tal análise mostra-se especialmente oportuna devido ao seu grande potencial heurístico, já que pode permitir um aporte crítico mais agudo em relação às ideologias nativas de cada etnia acerca do "sucesso" ou "fracasso" de cada corrente imigratória que se estabeleceu no país.

Por outro lado, do ponto de vista da sociologia dos fluxos migratórios atuais, ainda que estes sejam menos relevantes numericamente, importa analisar e avaliar as possibilidades de "assimilação" que se apresentam, segundo essas mesmas características próprias a cada grupo. Será que, por exemplo, bolivianos e coreanos, chegados a São Paulo em décadas mais recentes, embora possam trabalhar no mesmo bairro do Bom Retiro, apresentam experiências e estratégias de inserção social comuns? Se ocorrer, suas famílias e seus filhos são ou serão incorporados ao mainstream da sociedade paulistana da mesma forma? Guardam (ou se despojam de) suas características étnicas distintivas seguindo um mesmo padrão e com a mesma intensidade? E o que dizer dos imigrantes africanos chegados há menos tempo? E os muçulmanos instalados no Brás, em Santo Amaro e imediações, ou na região do $A B C$, que ganham a vida comercializando roupas e móveis? Terão as mesmas estratégias de seus conterrâneos instalados em Foz do Iguaçu? O fim de uma conjuntura recessiva, muito presente até os anos noventa, e a retomada recente do emprego e do crescimento econômico, ao acelerar a mobilidade, vêm favorecendo a incorporação de imigrantes ao tecido social? Há, portanto, uma pauta evidente de questões que merecem ser mais bem analisadas à luz do novo conceito de assimilação proposto por Alba e Nee e das novas reflexões que vêm sendo reelaboradas tendo por base o mesmo tema da incorporação de imigrantes ocorrida nos países platinos. Por sua relevância e peculiaridades, o caso nacional ou melhor, os casos nacionais em suas variantes regionais específicas podem contribuir para a formulação de teorias mais amplas na área dos estudos migratórios, ao mesmo tempo em que o novo conceito de "assimilação" pode contribuir para uma compreensão mais refinada de nossa(s) experiência(s) específica(s) de incorporar imigrantes ao tecido social. O desafio, para os que se dedicam à sociologia das migrações, é fazê-lo.

(Recebido para publicação em agosto de 2011)

(Reapresentado em maio de 2012)

(Aprovado para publicação em maio de 2012) 


\section{NOTAS}

1. Preservar no sentido de impedir a imigração de grupos alienígenas dotados de características físicas e culturais muito distantes do padrão nacional. Tomem-se, como exemplo, os debates sobre a imigração de chineses ao final do Império e de japoneses ao final dos anos trinta.

2. Para uma visão aprofundada de como tais teorias se difundiram e foram apreendidas não apenas no Brasil, mas em toda a América Latina, consultar Stepan (2005).

3. Em seus termos, "quanto aos estrangeiros, (...) que se vão espalhando por todo o país, especialmente o Norte e o grande Oeste. Nada de aglomerá-los às dezenas e centenas de milhares de uma só raça nas quatro províncias do sul" (Romero, 1959:38). Consultar também a dissertação de Pinto (1996:130).

4. Nesse sentido, afasta-se da visão de outros cientistas da época, como o médico baiano Nina Rodrigues, que adere às teorias de Lombroso e Gobineau, interpretando a mestiçagem como modelo de degenerescência.

5. Para uma análise pormenorizada dos argumentos utilizados por Vianna, consultar Ramos (2003).

6. Consultar as citações de Miguel Calmon, Gilberto Amado, Basílio de Magalhães, Afrânio Peixoto e José Maria Belo trazidas ao texto de Skidmore (1976).

7. Consultar também Lima e Hochman (1996).

8. Como observou Skidmore (1976:216), ao final dos anos vinte, a confiança no embranquecimento progressivo do país já permitia o reconhecimento de que "o africano havia dado estimável contribuição à construção do Brasil, mas era um elemento étnico inferior", o que o excluía a priori da definição de uma política imigratória, apesar de a vinda de qualquer contingente ser, àquela altura, altamente improvável.

9. Cf. cap. II, art. $3^{\circ}$, alíneas $f$ e g, respectivamente, do decreto que instituiu o Conselho.

10. A esse respeito, Willems (1951:209) observou, por exemplo, em tom ao mesmo tempo crítico e irônico, que, no Brasil, "assume-se que estes grupos devem ser 'absorvidos', 'digeridos', 'diluídos' ou qualquer que seja a metáfora biologicamente ou quimicamente colorida utilizada para indicar que os grupos alienígenas devem cessar de existir como unidades socioculturais distintas, e se fundir na sociedade brasileira sem deixar padrões divergentes no todo nacional".

11. Além da referência acima, consultar também Seyferth (2000b:48-49).

12. Acompanhando Pereira (1994:250), pode-se assim dizer que os estudos de Willems sobre os alemães jogam "com três vertentes temáticas - etnia, vida rural e comunidade". Igualmente, Melatti (1984) observou que alguns trabalhos sobre aculturação de imigrantes alemães, japoneses e italianos tomaram a forma de "estudo de comunida$\mathrm{de}^{\prime \prime}$. Este autor arrola uma série de estudos de comunidade focados em grupos de imigrantes.

13. Willems (1947). No cenário da sociologia paulista à época, a tradição dos estudos de comunidade era mais forte na Escola Livre de Sociologia e Política, trazida pela presença do próprio Willems e de Donald Pierson, ambos influenciados pela Escola de Chicago (Limongi, 2001).

14. Schaden publicou um artigo comparando a aculturação de alemães e japoneses na Revista de Antropologia. 
15. Vide também Durham (1982).

16. Consultar, por exemplo, em Hollanda (1979) o capítulo dedicado a analisar o trabalho de Willems sobre Cunha. Outro tipo de crítica, distinta, foi a formulada por Guerreiro Ramos (1954:78), para quem uma sociologia engajada politicamente deveria buscar soluções para os problemas nacionais.

17. Percebe-se já aqui a influência de sociólogos, como Eisenstadt, sobre o trabalho de antropólogos, em uma perspectiva que buscasse entender como processos socioeconômicos poderiam explicar transformações culturais. Tudo isso em contraposição aos estudos de aculturação de caráter mais estático e descritivo que, como Willems acreditava, devia suas causas últimas a processos psíquicos de ajustamento de valores e atitudes.

18. Mais uma vez, o próprio título de sua dissertação de mestrado (Assimilação e Mobilidade: A História do Imigrante Italiano num Município Paulista) refletia tal perspectiva de análise.

19. Não por acaso, mais tarde, ambas seriam responsáveis pelo desenvolvimento de linhas de pesquisa em antropologia urbana durante as décadas de 1970 e 1980 na USP.

20. Embora muito influente, a obra de Milton Gordon, anteriormente citada e publicada em 1964, já marca o declínio de tal concepção.

21. Para distinções mais precisas entre os termos, consultar Cashmore (1996:275-276; 244-246).

22. Para ela, as obras no Brasil mais influenciadas por este autor foram as de Vieira (1973) e de Rattner (1977).

23. Após distinguir entre dois significados para o termo assimilação - o primeiro abstrato e geral, no sentido de significar aumento de similaridade ou semelhança; o segundo específico e orgânico, no sentido de converter e absorver - o autor defende, julgando mesmo indispensável, a utilização sociológica do conceito no primeiro sentido (Brubaker, 2001:544).

24. Resumidamente, o chamado modelo pluralista advoga a conservação ou mesmo o incremento das características étnicas de cada grupo e das fronteiras entre grupos, ao longo de gerações; o transnacionalismo, por sua vez, chama a atenção para a referência identitária e cultural simultânea a países de origem e destino dos imigrantes; enquanto o modelo da assimilação segmentada enfatiza a consolidação de um determinado grupo como minoria prejudicada e marginal, impossibilitada de ascender socialmente de uma geração à outra.

25. Como, por exemplo, guerras no país de origem que mobilizam a etnicidade dos grupos imigrados.

26. No caso nacional, Seyferth $(1999 ; 2000 b)$ mostra, por exemplo, como as identidades dos imigrantes colidiram com os preceitos de abrasileiramento no contexto da imigração para o sul do Brasil.

27. Como uma pessoa é tratada pela sociedade depende não do que ela é, mas da maneira pela qual é definida (cf. o conceito de definição da situação, desenvolvido por Mead (1934)).

28. Neste, a sociedade é entendida como sistema social homogêneo, integrado por normas e valores centrais, no qual o equilíbrio estável entre estruturas e funções dos subcomponentes do sistema sustentam a ordem social. Tal noção é perfeitamente com- 


\section{Oswaldo Truzzi}

patível com a noção que enxerga a cultura e sociedade da classe média anglo-americana como ponto final da assimilação.

29. Apresentando uma série de dados empíricos, os autores argumentam, por exemplo, como após a Segunda Guerra Mundial, judeus e católicos e, mais recentemente a partir dos anos setenta, asiáticos, foram incorporados ao mainstream americano, caracterizando efetivamente processos de alteração de fronteiras.

30. Embora, se isso acontecer em larga escala, a estrutura social será alterada.

31. Os autores mostram, por exemplo, como, ao longo do tempo, a decisão de passar a residir em zonas mais afastadas do centro da cidade, favoreceu o relacionamento, como vizinhos, de grupos de origens étnicas e raciais diversas e, por consequência, a assimilação.

32. Sem prejuízo do reconhecimento, também, da existência de mecanismos de exploração de conterrâneos, no interior do próprio grupo.

33. Além da política em si, é muito importante aqui seu enforcement, ou seja, o monitoramento e a exigência de cumprimento da mesma.

34. Recorde-se aqui que economias em pleno crescimento garantem espaço para todos, abrindo oportunidades e fazendo com que os imigrantes possam conquistar, sobretudo, posições novas no tecido social, sem necessidade de deslocar velhas elites (Hutchinson, 1959). Tal situação de mobilidade, como já se viu, pode obviamente contribuir para a assimilação.

35. Nos termos de Pierre Bourdieu, das estruturas de capitais (econômico, social, político e cultural) apresentadas.

36. É interessante mencionar aqui o quanto, por exemplo, as trajetórias de mobilidade social das chamadas etnias comerciais (sírios, libaneses, judeus, armênios etc.) se assentaram sobre experiências com o comércio ou com um modo de vida urbano, adquiridas ainda na terra de origem.

37. A esse respeito, é notável o paralelismo com Florestan Fernandes no tocante ao papel de agente modernizador atribuído à burguesia imigrante (sobretudo em relação aos negros) em A Revolução Burguesa no Brasil.

38. Consultar, por exemplo, os numerosos artigos publicados em Estudios Migratorios Latinoamericanos, revista sediada em Buenos Aires e especializada no tema.

39. Que tampouco pode ser tratado indistintamente, no mínimo devendo-se distinguir o espaço polarizado pela capital das zonas mais antigas do interior e das zonas mais novas a oeste do estado. 


\section{REFERÊNCIAS BIBLIOGRÁFICAS}

ALBA, Richard e NEE, Victor. (2003), Remaking the American Mainstream. Assimilation and Contemporary Immigration. Cambridge, Harvard University Press.

ALBERSHEIM, Úrsula. (1962), Uma Comunidade Teuto-brasileira (Jarim). Rio de Janeiro, $\mathrm{CBPE} / \mathrm{MEC}$.

AZEVEDO, Thales. (1981), Italianos e Gaúchos. Rio de Janeiro/Brasília, Cátedra/Pró Memória.

BAlHANA, Altiva Pilatti. (1968), Santa Felicidade: Um Processo de Assimilação. Curitiba, João Haupt.

BARRON, Hal. (2004), Great Plains Research, 14, 2. pp. 347-349.

BARTH, Fredrik. (1998), “Grupos Étnicos e suas Fronteiras”, in P. Poutignat (org.), Teorias da Etnicidade. São Paulo, Unesp.

BASCH, Linda Griffith; GLICK SCHILLER, Nina e BLANC-SZANTON, Cristina. (1994), Nations Unbound: Transnational Projects, Post-Colonial Predicaments and De-Territorialized Nation-States. Langhorne, PA, Gordon and Breach.

BEAN, Frank e STEVENS, Gillian. (2004), “Assimilation Redux". Contemporary Sociology, vol. 33, no 4 , pp. 404-407.

BRUBAKER, Rogers. (2001), “The Return of Assimilation? Changing Perspectives on Immigration and Its Sequels in France, Germany and the United States". Ethnic and Racial Studies, vol. 24, no 4, pp. 531-548.

CANDIDO, Antonio. (1982), Os Parceiros do Rio Bonito. 6a ed. São Paulo, Duas Cidades.

CARDOSO, Ruth. (1972), Estrutura Familiar e Mobilidade Social: Estudo dos Japoneses no Estado de São Paulo. Tese de doutorado, FFLCH/USP, São Paulo.

(1961), "Santa Felicidade: Um Processo de Assimilação, de Altiva Pilatti Balhana". Revista de Antropologia, vol. 9, nos 1 e 2.

CASHMORE, Ellis. (1996), Dictionary of Race and Ethnic Relations. London, Routledge and Keagan Paul.

CONZEN, Kathleen Neils et alii. (1992), "The Invention of Ethnicity: a Perspective from the U.S.A.". Journal of American Ethnic History, vol. 12, pp. 3-41.

CORRÊA, Mariza. (1995), “A Antropologia no Brasil (1960-1980)”, in S. Miceli (org.), História das Ciências Sociais no Brasil, vol. 2. São Paulo, Sumaré.

DEVOTO, Fernando. (1992), “Del Crisol al Pluralismo: 30 Años de Historiografia sobre las Migraciones Europeas a la Argentina". Série Documentos de Trabajo, no 118, Buenos Aires, Instituto Di Tella.

e OTERO, Hernan. (2003), “Veinte Años Después. Una Lectura sobre el Crisol de Razas, el Pluralismo Cultural y la Historia Nacional en la Historiografia Argentina". Estudios Migratorios Latinoamericanos, vol. 50, pp. 181-227.

DIEGUES JR., Manuel. (1964), Imigração, Colonização e Industrialização. Rio de Janeiro, $\mathrm{CBPE} / \mathrm{MEC}$. 


\section{Oswaldo Truzzi}

DURHAM, Eunice. (2004). A Dinâmica da Cultura. Ensaios de Antropologia. São Paulo, Cosac Naify.

(1982), "Os Problemas Atuais da Pesquisa Antropológica no Brasil". Revista de Antropologia, vol. 25.

EISENSTADT, Shmuel Noah. (1954), The Absorption of Immigrants. A Comparative Study Based mainly on the Jewish Community in Palestine and the State of Israel. London, Routledge \& Kegan Paul.

ELLIS JR., Alfredo. (1934), Populações Paulistas. São Paulo, Companhia Editora Nacional.

FAUSTO, Boris. (1991), Historiografia da Imigração para São Paulo. São Paulo, Sumaré.

FERNANDES, Florestan. (1975), A Revolução Burguesa no Brasil. Ensaio de Interpretação Sociológica. Rio de Janeiro, Zahar.

GANS, Herbert. (1979), "Symbolic Ethnicity: The Future of Ethnic Groups and Cultures in America". Ethnic and Racial Studies, vol. 2, no 1, pp. 1-20.

GERMANI, Gino. (1987), Estructura Social de la Argentina. Buenos Aires, Solar.

GLAZER, Nathan. (1993), “Is Assimilation Dead?” Annals of the American Academy of Political and Social Science, vol. 530, pp. 122-136.

e MOYNIHAN, Daniel P. (1963), Beyond the Melting Pot: The Negroes, Puerto Ricans, Jews, Italians and Irish of New York. Cambridge, MIT Press.

GOEBEL, Michael. (2010), “Gauchos, Gringos and Gallegos: The Assimilation of Italian and Spanish Immigrants in the Making of Modern Uruguay, 1880-1930". Past \& Present, vol. 208, pp.191-229.

GORDON, Milton M. (1964), Assimilation in American Life. New York, Oxford University Press.

HAO, Lingxin. (2005), Social Forces. 84, 2, pp. 1309-1311.

HOLLANDA, Sérgio Buarque de. (1979), Tentativas de Mitologia. São Paulo, Perspectiva.

HUTCHINSON, Bertran. (1959), Mobilidade e Trabalho. Rio de Janeiro, INEP.

JORRAT, Jorge Raúl e SAUTU, Ruth (orgs.). (1992), Después de Germani. Exploraciones sobre Estructura Social de la Argentina. Buenos Aires, Paidós.

KAZAL, Russell A. (1995), "Revisiting Assimilation: The Rise, Fall, and Reappraisal of a Concept in American Ethnic History". The American Historical Review, vol. 100, no 2, pp. 437-471.

LIMA, Nísia Trindade e HOCHMAN, Gilberto. (1996), “Condenado pela Raça, Absolvido pela Medicina: O Brasil Descoberto pelo Movimento Sanitarista da Primeira República", in M. C. Maio e R. V. Santos (orgs.), Raça, Ciência e Sociedade. Rio de Janeiro, Ed. Fiocruz.

LIMONGI, Fernando. (2001), "A Escola Livre de Sociologia e Política em São Paulo", in S. Miceli (org.), História das Ciências Sociais no Brasil (2a ed.). São Paulo, Sumaré, pp. 257-75, vol. 1 .

MARTES, Ana Cristina e FAZITO, Dimitri. (2010), “Solidarity and Social Networks: Economic Sociology of International Migration and the Brazilian Case". Economic Sociology. The European Electronic Newsletter, vol. 11, no 3, pp. 43-53. 
MASSEY, Douglas S. (2004), "Review: Revenge of the Chicago School”. Contemporary Sociology, 33, 4, pp. 408-10.

MEAD, George Herbert. (1934), Mind Self and Society from the Stand point of a Social Behaviorist (editado por Charles W. Morris). Chicago, University of Chicago Press.

MELATTI, Júlio César. (1984), “A Antropologia no Brasil: Um Roteiro”. BIB, no 17, pp. 3-52.

PARK, Robert E. (1921), Old World Traits Transplanted: The Early Sociology of Culture. New York, Harper Brothers.

PEIXOTO, Fernanda Areas e SIMÕES, Júlio Assis. (2003), “A Revista de Antropologia e as Ciências Sociais em São Paulo: Notas sobre uma Cena e alguns Debates". Revista de Antropologia, vol. 46, no 2, pp. 383-409.

PEREIRA, João Baptista Borges. (1994), “Emilio Willems e Egon Schaden na história da Antropologia". Estudos Avançados, vol. 8, no 22, pp. 249-253.

PERSONS, Stow. (1987), Ethnic Studies at Chicago, 1905-45. Urbana, University of Illinois Press.

PINTO, Ricardo. (1996), Silvio Romero: Contribuições à Formação do Pensamento Racial no Brasil (1870-1914). Dissertação de mestrado. São Paulo, FFLCH-USP.

PORTES, Alejandro. (2004), “Convergências Teóricas e Dados Empíricos no Estudo do Transnacionalismo Imigrante". Revista Crítica de Ciências Sociais, no 69, pp. 73-93. e ZHOU, Min. (1993), “The New Second Generation: Segmented Assimilation and Its Variants". Annals of the American Academy of Political and Social Science, no 530.

RAMOS, Guerreiro A. (1954), A Cartilha Brasileira do Aprendiz de Sociólogo (Prefácio a uma Sociologia Nacional). Rio de Janeiro, Andes.

RAMOS, Jair Sousa. (2003), “Ciência e Racismo: Uma Leitura Crítica de Raça e Assimilação em Oliveira Vianna". História, Ciências, Saúde - Manguinhos, vol. 10, no 2.

. (1996), “Dos Males que Vêm com o Sangue: As Representações Raciais e a Categoria do Imigrante Indesejável nas Concepções sobre Imigração da Década de 20", in M. C. Maio e R. V. Santos (orgs.), Raça, Ciência e Sociedade. Rio de Janeiro, Ed. Fiocruz.

RATTNER, Henrique. (1977), Tradição e Mudança. São Paulo, Ática.

ROMERO, Nelson (org.). (1959), Silvio Romero: Trechos Escolhidos. Rio de Janeiro, Agir.

SAITO, Hiroshi. (1961), O Japonês no Brasil. Estudo de Mobilidade e Fixação. São Paulo, Nacional.

e MAEYAMA, Takashi (orgs.). (1973), Assimilação e Integração de Japoneses no Brasil. Rio de Janeiro/São Paulo, Vozes/Edusp.

SCHADEN, Egon. (1956), "Aculturação de Alemães e Japoneses no Brasil". Revista de Antropologia, vol. IV, no 1 .

SCHWARCZ, Lilia K. Moritz e QUEIROZ, Renato da Silva. (1996), Raça e Diversidade. São Paulo, Edusp.

SEYFERTH, Giralda. (2004), “A Imigração no Brasil. Comentários sobre a Contribuição das Ciências Sociais". BIB, no 57, pp. 7-47. 


\section{Oswaldo Truzzi}

. (2000a), “Assimilação dos Imigrantes no Brasil: Inconstâncias de um Conceito Problemático". Travessia. Revista do Migrante, no 36, pp. 45-50.

(2000b), "As Identidades dos Imigrantes e o Melting Pot Nacional". Horizontes Antropológicos, vol. 6, № 14.

(1999), "Os Imigrantes e a Campanha de Nacionalização do Estado Novo", in D. Pandolfi (org.), Repensando o Estado Novo. Rio de Janeiro, FGV Editora.

. (1996), “Construindo a Nação: Hierarquias Raciais e o Papel do Racismo na Política de Imigração e Colonização", in M. C. Maio e R. V. Santos (orgs.), Raça, Ciência e Sociedade. Rio de Janeiro, Ed. Fiocruz.

. (1988), "Imigração e Colonização Alemã no Brasil: Uma Revisão da Bibliografia". BIB, no 25, pp. 3-55.

SKIDMORE, Thomas. (1976), Preto no Branco: Raça e Nacionalidade no Pensamento Brasileiro. São Paulo, Paz e Terra.

STEPAN, Nancy Leys. (2005), A Hora da Eugenia: Raça, Gênero e Nação na América Latina. Rio de Janeiro, Ed. Fiocruz.

SYMPOSIUM ON REMAKING the American Mainstream: Assimilation and Contemporary Immigration". (2004), City \& Community 3:4.

TRUZZI, Oswaldo. (2008a) [1993], Patrícios, Sírios e Libaneses em São Paulo. 2a ed. São Paulo, Ed. Unesp.

(2008b), “Redes em Processos Migratórios". Tempo Social, vol. 20, pp. 199-218.

VIANNA, Francisco José de Oliveria. (1933a), Evolução do Povo Brasileiro. São Paulo, Cia. Ed. Nacional.

. (1933b), Raça e Assimilação. 2a ed. São Paulo, Cia. Ed. Nacional.

VIEIRA, Francisca. (1973), O Japonês na Frente de Expansão Paulista. São Paulo, Pioneira e Edusp.

WATERS, Mary. (1990), Ethnic Options: Choosing Identities in America. Berkeley, University of California Press.

WILLEMS, Emilio. (1951), "Immigrants and their Assimilation in Brazil”, in T. L. Smith e A. Marchant (eds.), Brazil: Portrait of Halfa Continent. New York, The Dryden Press.

(1950), Dicionário de Sociologia. Rio de Janeiro, Globo.

. (1947), Cunha. Tradição e Transição em uma Cultura Rural no Brasil. São Paulo, Secretaria da Agricultura.

. (1946), A Aculturação dos Alemães no Brasil: Estudo Antropológico dos Imigrantes Alemães e seus Descendentes no Brasil. São Paulo, Nacional [Col. Brasiliana].

. (1940), Assimilação e Populações Marginais no Brasil: Estudo Sociológico dos Imigrantes Germânicos e seus Descendentes. São Paulo, Cia. Ed. Nacional. 


\section{ABSTRACT}

Assimilation Resignified: new interpretations of an old concept

This article proposes an interpretation of the ways by which the term assimilation was used in Brazil in three different periods. It also presents a reconceptualization of the term based on Remaking the American Mainstream: Assimilation and Contemporary Immigration, by Richard Alba and Victor Nee, published originally in 2003. The argument is that the new formulation proposed by these authors can contribute to a more precise understanding of the different trajectories in the incorporation of foreign immigrant groups in Brazilian society in the past and present.

Key words: assimilation; immigration; national formation; cultural change; ethnicity; pluralism

\section{RÉSUMÉ}

Assimilation Resignifiée: Nouvelles Interprétations d'un Vieux Concept

Dans cet article, on propose une interprétation de la façon dont le concept d'“assimilation" a été employé au Brésil sur trois périodes différentes. On présente aussi une nouvelle conception de ce terme à partir de l'ouvrage Remaking the American Mainstream - Assimilation and Contemporary Immigration, de Richard Alba et Victor Nee, paru en 2003. On suppose que la nouvelle formulation proposée par ces auteurs peut contribuer à une compréhension plus exacte des différentes trajectoires d'incorporation de groupes d'immigrants étrangers à la société brésilienne, dans le passé et à présent.

Mots-clés: assimilation; immigration; formation nationale; changement culturel; ethnicité; pluralisme 